\title{
A Novel BMPR2 Mutation Associated with Pulmonary Arterial Hypertension in an Octogenarian
}

\author{
Shilpa Johri • Gan H. Dunnington • \\ Cindy L. Vnencak-Jones
}

Received: 19 October 2009/Accepted: 19 April 2010/Published online: 23 May 2010

(c) The Author(s) 2010. This article is published with open access at Springerlink.com

\begin{abstract}
We describe the case of an 83-year-old man with a family history of pulmonary hypertension $(\mathrm{PH})$ who presented with severe pulmonary arterial hypertension $(\mathrm{PAH})$ and later tested positive for a novel bone morphogenetic protein receptor 2 (BMPR2) gene mutation. To our knowledge, this may be the oldest reported patient with PAH in whom a $B M P R 2$ mutation was initially identified.
\end{abstract}

Keywords Heritable · Pulmonary arterial hypertension · $B M P R 2$ mutation

$\begin{array}{ll}\text { Abbreviations } \\ \text { BMPR2 } & \text { Bone morphogenetic protein receptor type } 2 \\ \text { DNA } & \text { Deoxyribonucleic acid } \\ \text { HPAH } & \text { Heritable pulmonary arterial hypertension } \\ \text { IPAH } & \text { Idiopathic pulmonary arterial hypertension } \\ \text { mRNA } & \text { Messenger ribonucleic acid } \\ \text { NMD } & \text { Nonsense mediated decay } \\ \text { PAH } & \text { Pulmonary arterial hypertension } \\ \text { PH } & \text { Pulmonary hypertension } \\ \text { TGF- } \beta & \text { Transforming growth factor- } \beta\end{array}$

S. Johri (凶)

Pulmonary Associates of Richmond, 1603 Santa Rosa Road, Suite 101, Richmond, VA 23229, USA

e-mail: shilpa.johri@gmail.com; sjohri@paraccess.com

G. H. Dunnington

Virginia Cardiovascular Specialists, 5875 Bremo Road, Suite

501, Richmond, VA 23226, USA

e-mail: gdunnington@vacardio.com

C. L. Vnencak-Jones

Molecular Genetics Laboratory, Department of Pathology,

Vanderbilt University Medical Center, 4918C TVC, Nashville,

TN 37232, USA

e-mail: cindy.vnencak-jones@Vanderbilt.Edu

\section{Introduction}

Pulmonary arterial hypertension (PAH) is a rare incapacitating disease with progressive functional limitation and deterioration to right heart failure and death. In addition to various disorders that can cause $\mathrm{PAH}$, a genetic predisposition to this disease was identified with the discovery of mutations in the gene encoding the bone morphogenetic protein receptor type 2 (BMPR2), a member of the transforming growth factor- $\beta$ (TGF- $\beta$ ) receptor, in both the familial and the sporadic cases of PAH [1-3]. Heritable $\mathrm{PAH}$ (HPAH) segregates as an autosomal-dominant disorder with variable age of onset, reduced penetrance, approximately a 2:1 female:male ratio, and genetic anticipation in some pedigrees [4-6]. Approximately $6 \%$ of the individuals diagnosed with PAH have a family history of this disorder. BMPR2 mutations are heterogeneous, with missense, nonsense, frameshift, splice site, and both small and large gene deletions and duplications found throughout the gene $[7,8]$. Disease-causing mutations have been identified in approximately $70 \%$ of HPAH and $5-26 \%$ of idiopathic PAH (IPAH) patients [8-11].

We present a novel BMPR2 mutation-associated case of PAH first diagnosed at 83 years of age. To the best of our knowledge, our patient may be the oldest to be diagnosed with $B M P R 2$-associated PAH.

\section{Case Report}

An 83-year-old World War II veteran presented for evaluation of fatigue and breathlessness with exertion at New York Heart Association III functional class with findings of elevated right-sided pressures on echocardiogram. He gave a history of progressive dyspnea with physical activity for 
4 years and pedal edema for 6 months which was symmetrical and worse during the evenings.

His past medical history included mild hypertension, nocturnal hypoxemia requiring oxygen therapy, gout, and degenerative arthritis of his right knee from shrapnel injury during World War II. He had an episode of syncope approximately 1 year prior to evaluation that was attributed to dehydration and heat exhaustion. Echocardiogram done at that time had shown preserved left ventricular ejection fraction at $70 \%$, enlarged right-sided chambers, and estimated right ventricular systolic pressures of $80 \mathrm{mmHg}$. He had no history of thromboembolic disease, chronic lung disease, or prior transfusions. He was on treatment with amlodipine for systemic hypertension, furosemide, and oxygen.

He had been a lifelong nonsmoker with no other dependence. He recalled his mother (nonsmoker) was diagnosed with pulmonary hypertension $(\mathrm{PH})$ and emphysema and had died at age 65. His brother and a maternal first cousin had died with a diagnosis of $\mathrm{PH}$ at age 49 and 71, respectively. The patient remembered that $\mathrm{PH}$ was identified on echocardiograms in his affected relatives but did not recollect details of other diagnostic workup. One of his brothers died of cirrhosis while his youngest brother was alive and had a history of coronary artery disease. His sister was alive and healthy. The patient had never married and had no children.

On examination his blood pressure was $92 / 61 \mathrm{mmHg}$, heart rate was $105 / \mathrm{min}$, respiratory rate was $18-20 / \mathrm{min}$, oxygen saturation was $92 \%$ on room air, and body mass index was $26.6 \mathrm{~kg} / \mathrm{m}^{2}$. Abnormal findings on examination included accentuated pulmonic component of second heart sound, 3/6 pansystolic murmur at the left lower sternal border, and bilateral pitting pedal edema.

Abnormal laboratory parameters included a brain natriuretic peptide of $335 \mathrm{pg} / \mathrm{ml}$, serum creatinine of $1.4 \mathrm{mg} / \mathrm{dl}$, and hemoglobin of $18 \mathrm{~g} / \mathrm{dl}$. Chest X-ray showed cardiomegaly, prominent pulmonary vasculature, and normal lung fields. Pulmonary function tests revealed normal spirometry, lung volumes, and diffusion capacity. Polysomnogram confirmed sleep-disordered breathing with obstructive, mixed, and central apneas. He was started on nocturnal continuous positive airway pressure with oxygen therapy. Electrocardiogram showed right axis deviation, right ventricular hypertrophy, and inverted $\mathrm{T}$ waves in V1V4. Echocardiogram was repeated and showed marked dilatation of right atrium and ventricle, impaired systolic right ventricular function, moderate to severe tricuspid regurgitation, and estimated peak pulmonary artery pressures of $100 \mathrm{mmHg}$ with left ventricular ejection fraction of $55 \%$ without segmental wall motion abnormalities or pericardial effusion. Adenosine stress test did not show ischemia or infarction. A 6-min walk test was severely impaired with a total distance of $67.06 \mathrm{~m}$ or $30.9 \%$ of the predicted lower limit of normal calculated to be $216.8 \mathrm{~m}$ for his age and body mass index using the Enright and Sherrill formula [12]. He stopped after 3 min because of breathlessness. Ventilation perfusion scan did not reveal perfusion defects or ventilation perfusion mismatch. Collagen vascular workup and hepatitis screen were negative, and HIV testing was not done as he denied risk factors. Right heart catheterization confirmed pulmonary arterial hypertension with pulmonary artery pressures of 102/ $44 \mathrm{mmHg}$ (mean $=63 \mathrm{mmHg}$ ), mean pulmonary artery occlusive pressure of $9 \mathrm{mmHg}$, mean right atrial pressure of $19 \mathrm{mmHg}$, mixed venous saturation of $61.5 \%$, thermodilution cardiac output of $2.72 \mathrm{l} / \mathrm{min}$, and cardiac index and pulmonary vascular resistance calculated at $1.48 \mathrm{1} / \mathrm{min} / \mathrm{m}^{2}$ and $1588 \mathrm{dyn} \mathrm{s} / \mathrm{cm}^{5}$, respectively. Acute vasodilator study with inhaled nitric oxide did not show vasoreactivity.

With a family history of relatives carrying a diagnosis of $\mathrm{PH}$, genetic testing was offered to assess for the presence of HPAH. Using previously described techniques, BMPR2 DNA and RNA mutation screening was performed upon peripheral lymphocytes and identified mutation c.241insT in exon 2 of the BMPR2 gene (Fig. 1) [8]. This diseasecausing mutation in codon 81 replaced lysine with a stop codon.

Amlodipine was stopped and he was started on digoxin, warfarin, and bosentan, which was titrated to a target dose of $125 \mathrm{mg}$ two times a day. At the time of his last office

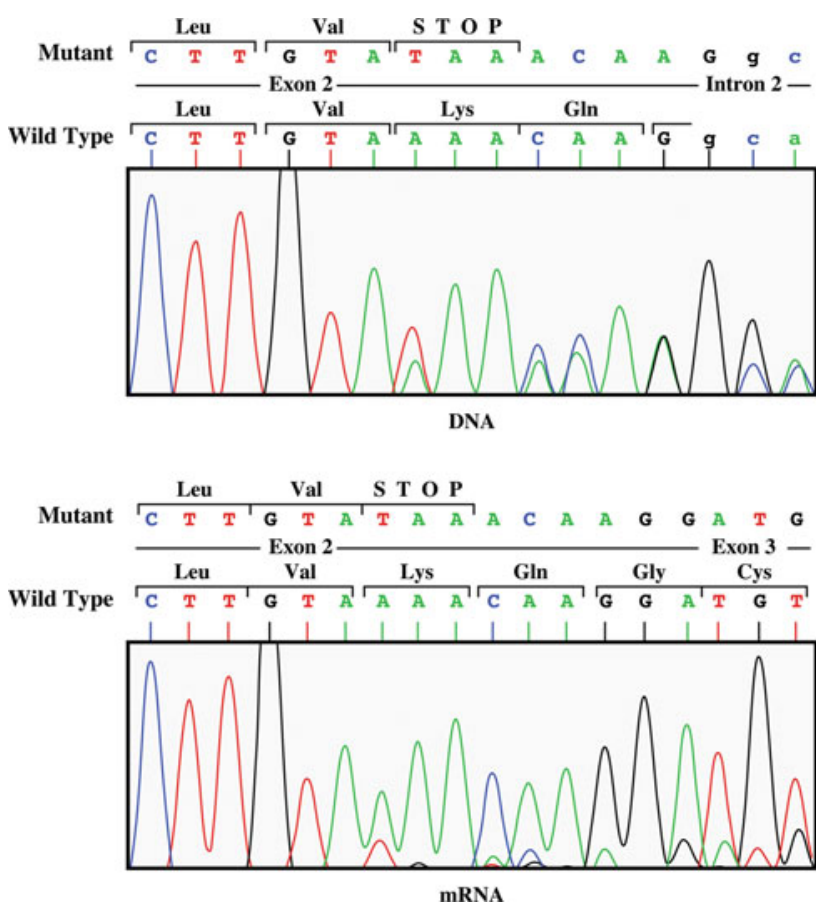

Fig. 1 Sequencing results demonstrating mutation c.241insT in DNA and mRNA 
visit and after a year of bosentan therapy, he reported better tolerance for physical activity with improvement in functional class to NYHA II. His 6-min walk distance had improved to $146.3 \mathrm{~m}(67.5 \%$ of predicted lower limit of normal [12]) and was mainly limited by knee pain. Followup right heart catheterization showed a right atrial mean pressure of $3 \mathrm{mmHg}$, pulmonary artery pressure of 95/ $20 \mathrm{mmHg} \quad$ (mean $=45 \mathrm{mmHg}$ ), pulmonary capillary wedge pressure of $6 \mathrm{mmHg}$, cardiac output of $2.9 \mathrm{l} / \mathrm{min}$, and calculated cardiac index and pulmonary vascular resistance of $1.6 \mathrm{l} / \mathrm{min} / \mathrm{m}^{2}$ and $1075 \mathrm{dyn} \mathrm{s} / \mathrm{cm}^{5}$, respectively. His extended family had undergone genetic counseling but declined genetic testing.

\section{Discussion}

We describe the case of an 83-year-old man presenting with pulmonary arterial hypertension due to a previously unreported BMPR2 mutation c.241insT. This DNA single base insertion at codon 81 results in a frameshift with a stop codon at this site causing premature truncation of the $B M P R 2$ protein. This mutation creates messenger ribonucleic acid (mRNA) that would be identified and subjected to nonsense-mediated decay (NMD) [13]. Interestingly, a low level of aberrant mRNA was detected in the lymphocytes from this patient (Fig. 1).

This case is interesting in that this patient presented at the age of 83. Recently, Sztrymf et al. [14] reported that PAH carriers of $B M P R 2$ mutations presented 10 years earlier than IPAH patients $(36.5 \pm 14.5$ vs. $46.0 \pm 16.1)$. Carriers of BMPR2-truncating mutations (NMD positive) have a later age of diagnosis and death than carriers of a $B M P R 2$ missense mutation (NMD negative) [15]. This recent study of NMD-associated BMPR2 mutations provides additional evidence of the protective function of NMD in heterozygote carriers of dominant disorders [16]. Since only $10-20 \%$ of individuals with a BMPR2 mutation develop PAH, it is suggested that both environmental factors and modifier genes explain the reduced penetrance of HPAH [17-21]. Single nucleotide polymorphisms in the TGF $\beta 1$ gene and variations in genes associated with proliferation, GTP signaling, stress response, and estrogen metabolism have been proposed to modulate the age of diagnosis and penetrance in these families [18, 19]. Recently, expression of wild-type allele BMPR2 transcripts has been reported as being important in determining penetrance of HPAH [20]. Thus, the late age of onset in our patient can be likely explained by a NMD-positive BMPR2 mutation and the presence of modifier genes and/or unknown environmental factors which conveyed protection from PAH at an earlier age. It is interesting that the mutant $B M P R 2$ mRNA was detected at a low level in the lymphocytes of the patient and apparently escaped complete NMD in this tissue. The status of the mutant BMPR2 mRNA in the lung of the patient is unknown. However, if the mutant BMPR2 mRNA also escaped complete degradation by NMD in the lung tissue of our patient, it is then presumed that the severely truncated mutant protein was unable to interfere effectively with the function of the wild-type $B M P R 2$ protein in a dominantnegative manner. Thus, one would predict that this patient probably developed PAH through haploinsufficiency of the $B M P R 2$ protein [17].

\section{Conclusion}

Clinical testing for BMPR2 mutations is appropriate care for the management of patients with a family history of PAH regardless of the age at presentation as detection of familyspecific mutations can be used to counsel family members at risk for developing PAH. Identification and analysis of different mutations will help understand the disease at a genetic level and explore treatment options that can be offered to patients and their families with HPAH. The future holds promise for targeting therapies at a molecular level.

Prior to proceeding with presymptomatic genetic testing, counseling to discuss the complexity of this disease and the reduced risk for developing the disease in the presence of the mutation is required.

Acknowledgments We thank Anand Lothe, MD, for referring this patient, and Lisa Wheeler, Vanderbilt University Medical Center, for coordinating testing and genetic counseling of the patient and his family.

Disclosure The authors have no conflicts of interest or financial ties to disclose.

Open Access This article is distributed under the terms of the Creative Commons Attribution Noncommercial License which permits any noncommercial use, distribution, and reproduction in any medium, provided the original author(s) and source are credited.

\section{References}

1. Deng Z, Morse JH, Slager SL, Cuervo N, Moore KJ, Venetos G, Kalachikov S, Cayanis E, Fischer SG, Barst RJ, Hodge SE, Knowles JA (2000) Familial primary pulmonary hypertension (gene PPH1) is caused by mutations in the bone morphogenetic protein receptor II gene. Am J Hum Genet 67:737-744

2. International PPH Consortium, Lane KB, Machado RD, Pauciulo MW, Thomson JR, Phillips JA 3rd, Loyd JE, Nichols WC, Trembath RC (2000) Heterozygous germline mutations in $B M P R 2$, encoding a TGF-beta receptor, cause familial primary pulmonary hypertension. Nat Genet 26:81-84

3. Newman JH, Wheeler L, Lane KB, Loyd E, Gaddipati R, Phillips JA 3rd, Loyd JE (2001) Mutation in the gene for bone morphogenetic protein receptor II as a cause of primary pulmonary hypertension in a large kindred. N Engl J Med 345:319-324 
4. Rich S, Dantzker DR, Ayres SM, Bergofsky EH, Brundage BH, Detre KM, Fishman AP, Goldring RM, Groves BM, Koerner SK et al (1987) Primary pulmonary hypertension. A national prospective study. Ann Intern Med 107:216-223

5. Gaine SP, Rubin LJ (1998) Primary pulmonary hypertension. Lancet 352:719-725

6. Loyd JE, Butler MG, Foroud TM, Conneally PM, Phillips JA 3rd, Newman JH (1995) Genetic anticipation and abnormal gender ratio at birth in familial primary pulmonary hypertension. Am J Respir Crit Care Med 152:93-97

7. Machado RD, Eickelberg O, Elliott CG, Geraci MW, Hanaoka M, Loyd JE, Newman JH, Phillips JA 3rd, Soubrier F, Trembath RC, Chung WK (2009) Genetics and genomics of pulmonary arterial hypertension. J Am Coll Cardiol 54:S32-S42

8. Cogan JD, Vnencak-Jones CL, Phillips JA 3rd, Lane KB, Wheeler LA, Robbins IM, Garrison G, Hedges LK, Loyd JE (2005) Gross BMPR2 rearrangements constitute a new cause for primary pulmonary hypertension. Genet Med 7:169-174

9. Cogan JD, Pauciulo MW, Batchman AP, Prince MA, Robbins IM, Hedges LK, Stanton KC, Wheeler LA, Phillips JA 3rd, Loyd JE, Nichols WC (2006) High frequency of BMPR2 exonic deletions/duplications in familial arterial hypertension. Am J Respir Crit Care Med 174:590-598

10. Thomson JR, Machado RD, Pauciulo MW, Morgan NV, Humbert M, Elliott GC, Ward K, Yacoub M, Mikhail G, Rogers P, Newman J, Wheeler L, Higenbottam T, Gibbs JS, Egan J, Crozier A, Peacock A, Allcock R, Corris P, Loyd JE, Trembath RC, Nichols WC (2000) Sporadic primary pulmonary hypertension is associated with germline mutations of the gene encoding BMPR-II, a receptor member of the TGF-beta family. J Med Genet 37:741-745

11. Aldred MA, Vijayakrishnan J, James V, Soubrier F, GomezSanchez MA, Martensson G, Galie N, Manes A, Corris P, Simonneau G, Humbert M, Morrell NW, Trembath RC (2006) $B M P R 2$ gene rearrangements account for a significant proportion of mutations in familial and idiopathic pulmonary arterial hypertension. Hum Mutat 27:212-213

12. Enright PL, Sherrill DJ (1998) Reference equations for the sixminute walk in healthy adults. Am J Respir Crit Care Med 158:1384-1387
13. Chang YF, Imam JS, Wilinson MF (2007) The nonsense-mediated decay RNA surveillance pathway. Ann Rev Biochem 76:5174

14. Sztrymf B, Coulet F, Girerd B, Yaici A, Jais X, Sitbon O, Montani D, Souza R, Simonneau G, Soubrier F, Humbert M (2008) Clinical outcomes of pulmonary arterial hypertension in carriers of BMPR2 mutation. Am J Respir Crit Care Med 177:1377-1383

15. Austin ED, Phillips JA, Cogan JD, Hamid R, Yu C, Stanton KC, Phillips CA, Wheeler LA, Robbins IM, Newman JH, Loyd JE (2009) Truncating and missense BMPR2 mutations differently affect the severity of heritable pulmonary arterial hypertension. Respir Res 10:87

16. Khajavi M, Inoue K, Lupski JR (2006) Nonsense-mediated mRNA decay modulates clinical outcome of genetic disease. Eur J Hum Genet 14:1074-1081

17. Newman JH, Phillips JA, Loyd JE (2008) Narrative review: the enigma of pulmonary arterial hypertension: new insights from genetic studies. Ann Intern Med 148:278-283

18. Phillips JA 3rd, Poling JS, Phillips CA, Stanton KC, Austin ED, Cogan JD, Wheeler L, Yu C, Newman JH, Dietz HC, Loyd JE (2008) Synergistic heterozygosity for TGF $\beta 1$ SNPs and BMPR2 mutations modulates the age at diagnosis and penetrance of familial pulmonary arterial hypertension. Genet Med 10:359-365

19. West J, Cogan J, Geraci M, Robinson L, Newman J, Phillips JA, Lane K, Meyrick B, Loyd J (2008) Gene expression in BMPR2 mutation carriers with and without evidence of pulmonary arterial hypertension suggests pathways relevant to disease penetrance. BMC Med Genomics 1:45

20. Hamid R, Cogan JD, Hedges LK, Austin E, Phillips JA 3rd, Newman JH, Loyd JE (2009) Penetrance of pulmonary arterial hypertension is modulated by the expression of normal BMPR2 allele. Hum Mutat 30:649-654

21. Rodriguez-Murillo L, Subaran R, Stewart WC, Pramanik S, Marathe S, Barst RJ, Chung WK, Greenberg DA (2010) Novel loci interacting epistatically with bone morphogenetic protein receptor 2 cause familiar pulmonary arterial hypertension. J Heart Lung Transplant 29(2):174-180 